\title{
Pediatric type 2 diabetes mellitus complications: a systematic review of the literature
}

\author{
Deovina $\mathrm{N}$ Jordan $^{1+*}$ and James $\mathrm{L}$ Jordan $^{2+}$ \\ *Correspondence: djordan@mednet.ucla.edu \\ ${ }^{\dagger}$ Authors' contributed equally. \\ ${ }^{1}$ Ronald Reagan UCLA Medical Center, 5 West, 757 Westwood Plaza, Los Angeles, CA 90095. \\ 2Jordan Research Institute, Murrieta, CA 92562.
}

\begin{abstract}
The incidence and prevalence of type 2 diabetes mellitus (T2DM) are increasing worldwide in the pediatric population. The increase has been attributed to obesity, lack of physical activity, improper diet, and family medical history. Type 2 diabetes mellitus has serious complications for children, including cardiovascular problems, dyslipidemia, hypertension, nonalcoholic fatty liver disease, pancreatic problems, pulmonary problems, and renal injury. Unfortunately, T2DM and its complications in the pediatric population remain largely understudied. As such, diabetes researchers, educators, and clinicians are forced to rely on information collected on adults with T2DM which may or may not be applicable to children with T2DM.
\end{abstract}

Keywords: pediatric diabetes, type 2 diabetes mellitus, diabetes complications, diabetes cardiac complications, diabetes dyslipidemia

\section{Foci of the review}

The foci of this paper are the epidemiology and pathophysiology of T2DM complications that occur in the pediatric population based on manuscripts that specifically address pediatric, not adult, T2DM. It is hoped that this review may be used as a basis to advance research on T2DM among children and, ultimately, to promote the timely and appropriate management and treatment of T2DM in children order to avoid the serious complications. The review does not address complications in the adult population. No inferences are made on metabolic syndrome; all the articles mentioned address T2DM. Also, the paper does not focus on the treatment of T2DM or its complications in children. Finally, it does not address research about type one diabetes mellitus (T1DM), nor does it make any inferences from T1DM to T2DM. It should be noted that many complications that occur among pediatric patients with T2DM can also present among adults with T2DM. But, that may not be true for everything.

\section{Review}

Type 2 diabetes mellitus (T2DM) was traditionally a disease of adulthood. Currently, the incidence and prevalence of T2DM are increasing among children and adolescents. In one study, about $45 \%$ of new cases of diabetes mellitus (DM) in the pediatric population were estimated to be T2DM [1]. However, firm rates of both incidence and prevalence of T2DM in children and adolescents are not available since T2DM is not reportable in any jurisdiction [2].
Because childhood risk factors for both cardiovascular disease (CVD) and T2DM may carry over into adulthood, universal screening of triglycerides, body mass index (BMI), and blood pressure (BP) has been advocated [3]. However, even the choice of screening methodology for T2DM among adolescents remains controversial [4]. The problem is compounded by the fact that most obese youth who are screened for diabetes also have normal fasting glucose levels [5].

The risk factors for the increase of T2DM in the pediatric population include obesity or BMI greater than $85 \%$ (which currently has a rate of about $49.3 \%$ ) [6] and other causes (including increased consumption of cheap foods such as high fructose corn syrup) [7]. Childhood obesity is even a problem in some developing countries. For example, $41.8 \%$ of children in Mexico, $22.1 \%$ of children in Brazil, $22.0 \%$ of children in India, and $19.4 \%$ of children in Argentina are classified as obese [8]. As the incidence of T2DM is dramatically increasing among the pediatric population, so will the complications of the disease. This has been attributed to the population's limited physical activity $[9, \mathbf{1 0}]$. The increasing problem of T2DM is also aggravated by the fact that the disease progresses faster among obese children than among adults [11]. Another challenge is that T2DM can be controlled by diet and exercise in only less than $10 \%$ of children with T2DM, thereby necessitating pharmacologic interventions [6].

Another factor in the increase of T2DM in children and adolescents is genetic influence. A strong family history of diabetes (FHD) is present in $45 \%$ to $80 \%$ of children

(c) 2012 Jordan et al; licensee Herbert Publications Ltd. This is an open access article distributed under the terms of Creative Commons Attribution License (http://creativecommons.org/licenses/by/3.0),This permits unrestricted use, distribution, and reproduction in any medium, provided the original work is properly cited. 
with T2DM [6]. Having diabetic parents is a risk factor for the development of T2DM among pre-pubertal Malays [12]. Children born to mothers with T2DM are particularly at increased risk for the disease when compared to children whose fathers had T2DM. The risk is higher for boys than for girls [13]. More females than males are diagnosed with T2DM during puberty; however, among adults, more males than females are diagnosed with T2DM [14]. An FHD is reflected in significantly lower serum adiponectin levels, independent of obesity. Yet, impaired glucose tolerance is about four times higher in obese children with a positive FHD than those who do not have a positive FHD [15]. Nevertheless, even though genetic factors are suggested by a strong FHD for T2DM, the molecular genetics is difficult to explain because of the very few subjects available for research and weak diagnostic criteria [16].

Nongenomic factors also play a role in the increase of T2DM in children and adolescents. Ninety-five percent of children in Canada with T2DM are obese and 37\% already have at least one complication on initial diagnosis of T2DM [17]. In a study in the United States (US), overweight and obesity were present in $10.4 \%$ and $79.4 \%$ respectively of pediatric patients with T2DM [18]. Finally, in a study in Japan, obesity was noted in $83 \%$ of the children with T2DM [19]. Also, in Japan, insulin resistance, a feature of T2DM, was noted to gradually increase with the increase in weight in these children [20]. Another factor, besides obesity, in the development of pediatric T2DM is the peak of physiological insulin resistance. The age of 13.5 years can bring about overt DM in persons at risk for the disease [21]. The problem is compounded among female adolescents. Earlier pubertal timing has also been associated with development of T2DM and cardiovascular disease later in life [22]. Possible factors include reductions in insulin sensitivity and $\beta$-cell function, along with increased total and truncal fat, in females who undergo early onset of menarche [23].

Much of the information applied to pediatric type 2 diabetics has been adopted directly from studies addressing adults with T2DM. For example, increasing insulin doses are required for pediatric patients, but not for adult patients, with T2DM. Second, if the child has ketoacidosis at initial diagnosis of T2DM, $\beta$-cell decline will be greater over time [24]. However, information regarding adults with T2DM may not always be applicable to children with the disease. Unfortunately, the literature on T2DM among the pediatric population remains limited. As such, much of the management and treatment for both T2DM and its complications in the pediatric population are based mostly on information gathered from the adult population [25]. The lack of information about pediatric T2DM may influence the care delivered by healthcare professionals. Wong, Potter, Mulvaney, Russell, and Schlundt [26] reported a wide variation in the management of pediatric T2DM. Even the diagnosis of T2DM is variable; many children with T2DM are incorrectly diagnosed as having T1DM [21]. On the other hand, some children with T1DM are incorrectly diagnosed as having T2DM. One reason for the misdiagnosis is that many children with T1DM are also overweight at initial diagnosis [27]. Finally, glucose homeostasis alterations in obese adolescents can present before alterations in glucose tolerance occur; as such, complications such as cardiovascular disease may have begun by the time of the T2DM diagnosis [28].

Because there is very limited information about the incidence, glycemic control, and early treatment of pediatric T2DM [29], it is important that critical gaps in literature be addressed. This paper is a systematic review of the current literature regarding pediatric T2DM and its complications. It aims to highlight what is known about pediatric T2DM and the complications of the disease in the pediatric population. It is hoped that this review may be used as a basis for a more timely and appropriate management and treatment of pediatric T2DM to avoid serious long-term complications. Only studies directly addressing pediatric T2DM have been included in this manuscript. Information is presented about the following T2DM complications in the pediatric population: cardiac complications, dyslipidemia, hypertension, nonalcoholic fatty liver disease, pancreatic complications, pulmonary complications, and renal injury.

\section{Cardiovascular complications}

Cardiorespiratory fitness is usually low among children with T2DM. Regular physical activity is recommended to increase cardiovascular health and decrease long-term complications from DM [30]. One long-term complication may be coronary heart disease. One reason for possible future coronary heart disease is that high density lipoprotein (HDL) size shifts to smaller particles in children with T2DM. A major cause for the shift is insulin resistance [31]. Insulin resistance that develops during a person's youth can lead to increases in both morbidity and mortality across that person's lifespan [32]. One pharmacologic intervention used to counter insulin resistance in pediatric patients has been the administration of Metformin [32,33].

The changes that occur for T2DM are mirrored by the changes observed for obesity [34]. For example, carotid intima-media thickness (CIMT) has been noted to be thicker and stiffer among obese adolescents with T2DM than among lean adolescents without T2DM [35]. The change in CIMT results in reduction in flow-mediated dilation [36] and indicates a possible trend toward concentric remodeling [37]. Duration of diabetes, poor glycemic control, increased C-reactive protein, and body mass index have been shown to be correlated positively with increased CIMT [38]. Even race may play a role in vascular stiffness among adolescents with T2DM; African-American adolescents with T2DM have greater vascular stiffness than do age-matched Caucasian adolescents with T2DM [39]. Urbina, Gao, Kloury, Martin and Dollan (2012) concluded that the increased arterial 
stiffness was associated with obesity and blood pressure, but not necessarily insulin resistance [40]. Regardless of the causative factor, the vascular changes can predispose obese adolescents with T2DM to stroke and myocardial infarction later in life [35].

In addition to macrovascular changes, T2DM can also present with major microvascular induced complications. In a study conducted in south India on 368 children and adolescents with T2DM, $26.7 \%$ presented with retinopathy, $14.7 \%$ with microalbuminuria, $14.2 \%$ with neuropathy, and $8.4 \%$ with nephropathy [41]. One reason for the increase in diabetic microvascular complications among adolescents with T2DM is because of increased hypercoagulability (due to elevated D-dimer and total serum cholesterol levels) [42]. However, even though retinal abnormalities (e.g., retinal venular dilation) occur very early in the course of T2DM [43], the clinical picture may remain occult during childhood and adolescence. For example, most diabetic retinopathy (DR) during childhood and adolescence remains only as background retinopathy [44]. Glycemic control during childhood and adolescence can help delay or prevent development of DR [44].

Even the brain might be affected by microvascular changes that occur from T2DM even before the onset of macrovascular disease [45]. Adolescents with T2DM were found to have significant reductions in hippocampal and prefontal volumes along with higher rates of global cerebral atrophy. Possibilities for causation include endothelialdependent vasodilation impairment by T2DM and reduced cerebrovascular reactivity to CO2. Previously, the effect of T2DM had been shown in older adults with T2DM and impaired cognitive function [45].

\section{Dyslipidemia}

Dyslipidemia occurs in individuals with T2DM and in those who are obese. In pediatric patients, dyslipidemia is significantly worse among those with T2DM when compared to those who are obese but without T2DM. Even with tight glycemic control, the dyslipidemia may persist. Nevertheless, primary data on dyslipidemia in pediatric T2DM patients remain limited [46]. The problem is compounded by differences among ethnic groups. For example, Canadian Aboriginal children with T2DM were less likely to present with dyslipidemia than White children with T2DM [17].

Elevated triglycerides occurred in the majority of Japanese pediatric patients with T2DM. Control of elevated triglycerides is important in preventing the development of cardiovascular disease [19] as dyslipidemia (including elevated triglycerides) is also a risk factor for the development of cardiovascular disease and atherosclerosis [46]. Malays (including Filipinos) are one group at high risk for both T2DM and dyslipidemia; the high incidence even occurs in the pediatric population [12]. However, even though T2DM, dyslipidemia, and hypertension during childhood may be antecedents for adult cardiovascular disease, screening for T2DM, dyslipidemia, and hypertension is not routinely practiced for pediatric patients [47].

\section{Hypertension}

Hypertension (HTN) is uncommon in the pediatric population [48]. However, HTN is more common among children with T2DM than children with T1DM [49]. Among children with T2DM, rates for HTN range from $12 \%$ to $36 \%$ [48]. At the time of diagnosis for HTN, it is often not possible to determine whether the DM is type 1 or type 2. The diagnostic issue is further complicated by the overlap between types 1 and 2 DM in obese adolescents [50]. Nevertheless, those who develop HTN need to be proactively managed, either therapeutically or by lifestyle changes, in order to reduce the occurrence of future cardiovascular disease [48]. Unfortunately, HTN is not commonly treated among children with T2DM [51].

The development of HTN also varies according to ethnicity. Malays (including Filipinos) have a higher risk for developing pediatric T2DM than other Asian groups [52]. Hypertension is a prevalent comorbidity or complication among Malay children with T2DM for which prevalence is similar to that in developed countries [53].

\section{Nonalcoholic fatty liver disease}

Nonalcoholic fatty liver disease (NAFLD) is indicated by elevated serum liver enzyme levels because of infiltration and accumulation of large triglyceride droplets within hepatocytes $[\mathbf{4 8 , 5 4 ]}$. In one study conducted in Canada, adolescents with T2DM had nearly three times as much hepatic triglyceride as adolescents of a comparable weight but without T2DM [55]. As a consequence of the elevated tryglyceride levels, NAFLD is associated with hypertriglyceridemia [54], elevated alanine transaminase (ALT) levels and vitamin D deficiency [56]. Elevated liver fat in obese Hispanic adolescents was also associated with elevated/increased serum IL-8, nerve growth factor (NGF), acute insulin response to glucose (AIR) and homeostasis model assessment of insulin resistance (HOMA-IR) [57]. Unfortunately, NAFLD is the most common cause of childhood liver disease [54] and is common in pediatric patients with T2DM, dyslipidemia, and abdominal obesity $[\mathbf{5 8}, \mathbf{5 9}]$. Approximately $3 \%$ to $10 \%$ of children overall and $40 \%$ to $70 \%$ of obese children have NAFLD $[60,61]$. But, the situation is far from hopeless. Nonalcoholic fatty liver disease, as well as reduced insulin sensitivity, may be reversible by application of even a short-term diet and exercise program that induces weight loss [62]. If left untreated, however, NAFLD is progressive and may ultimately lead to cirrhosis later in either childhood or adulthood $[63,64]$. Other complications for NAFLD include a possible progression to hepatocarcinoma, liver-related death in adulthood [63], and development of cardiovascular disease [59]. 
A diagnosis based upon elevated liver enzymes is not necessarily sufficient to diagnose NAFLD. If ALT levels are elevated three times the upper limit of normal for more than six months, an abdominal examination using ultrasound should be performed to rule out the possibility of viral hepatitis [64]. Liver biopsy is required for accurate diagnosis and staging of the NAFLD [65].

\section{Pancreatic complications}

First-phase insulin and C-peptide decline in obese adolescents with T2DM. $\beta$-cell function in overweight and obese adolescents is impaired relative to insulin sensitivity [66]. This is due to the $\beta$-cell function rapidly declining, even without significant changes occurring concurrently, with peripheral or hepatic insulin sensitivity [67]. At the time of diagnosis with T2DM, adolescents already present with $\beta$-cell dysfunction that is comparable to that observed in their adult counterparts [68]. In response to $\beta$-cell dysfunction, Sajaarda, Michaliszyn, Lee, Tfayli, and Bacha (2012) recommended the use of $\mathrm{HbA}(1 \mathrm{c})$ to be used as a screening tool to investigate the progression and even reversal of T2DM risk in such adolescents [66].

\section{Pulmonary complications}

Peak oxygen intake (indexed to fat mass) is adversely affected by T2DM during adolescence. When adolescents (aged 13-18 years old) were subjected to a graded maximal cycle ergometer test to exhaustion with indirect calorimetry, those with T2DM had 11\% lower peak oxygen intake than their counterparts who had a similar weight but without T2DM [55].

Type 2 diabetes mellitus can also adversely affect breathing during sleep. Insulin sensitivity is negatively correlated with sleep fragmentation and intermittent hypoxemia in adolescent males. This was shown to be independent of age and adiposity. Moreover, it may be a precursor to the development of T2DM in obese adolescents due to the emergence of metabolic impairment [69].

\section{Renal injury}

Chronic kidney disease and end-stage renal disease (ESRD) can have their origins in childhood, particularly for children who are obese and have T2DM. Kidney failure caused by either type 1 or type $2 \mathrm{DM}$ is uncommon during childhood. Children with T2DM are at higher risk for developing primary renal disease (e.g., IgA nephropathy, membranoproliferative glomerulonephritis) $[\mathbf{7 0 , 7 1 ]}$ and a four-fold increased risk for developing renal failure [72]. Children with T2DM also have a high risk of ESRD during early adulthood [73].

Years of hyperglycemia exert a contributing factor to the development of long-term complications [74]. As such, children diagnosed with T2DM should be screened with regards to glomerular filtration rate (GFR), blood pressure, and urinary albumin excretion rate (U-AER) [75]. Detection of microalbuminuria is the earliest possible marker for renal disease; it is also an independent predictor for future cardiovascular morbidity and mortality $[\mathbf{7 0 , 7 6}$. However, renal disease cannot be reliably determined solely by clinical and laboratory findings. Renal biopsy is needed to provide accurate diagnosis [77].

\section{Conclusions}

Although T2DM incidence and prevalence are increasing in the pediatric population, little is known about its serious complications in this population. Moreover, even when research is reported on the complications, the end results are still expressed in adulthood. Yet, the pathogenesis toward those end results needs to be investigated. Currently, diabetes researchers, educators, and clinicians rely mostly on information collected on adults with T2DM which may or may not be applicable to children with T2DM. To date, a number of complications have been identified regarding T2DM in children and adolescents including cardiovascular (coronary heart disease, macrovascular and microvascular changes, HTN), metabolic (dyslipidemia), hepatic (NAFLD), pancreatic ( $\beta$-cell dysfunction), pulmonary (altered peak oxygen intake, sleep disorders), and renal (chronic kidney disease, ESRD). However, a high likelihood exists that other complications can be identified with further clinically oriented research. It is hoped that this review of literature may be used as a basis for a more timely and appropriate management and treatment of pediatric T2DM in order to avoid the aforementioned serious long-term complications.

\section{List of abbreviations}

DM: Diabetes Mellitus

T1DM: Type 1 diabetes mellitus

T2DM: Type 2 diabetes mellitus

FHD: Family history of diabetes

DR: Diabetic retinopathy

HDL: High density lipoprotein

US: United States

NAFLD: Nonalcoholic fatty liver disease (NAFLD)

ALT: Alanine transaminase

HTN: Hypertension

ESRD: End stage renal disease

GFR: Glomerular filtration rate

\section{Competing interests}

The authors declare that they have no competing interests.

\section{Authors' contributions}

DJ and JJ both have made substantial and equal contributions to the following: conception of this manuscript, acquisition of data, writing of the manuscript, and checking it regularly and critically for important intellectual content. Both have read and given final approval of the version to be published.

\section{Publication history}

Received: 31-Aug-2012 Revised: 29-Nov-2012

Rerevised: 07-Dec-2012 Accepted: 11-Dec-2012

Published: 31-Dec-2012 


\section{References}

1. Mohamadi A and Cooke DW: Type 2 diabetes mellitus in children and adolescents. Adolesc Med State Art Rev. 2010, 21: 103-19. | PubMed

2. Shah SM: Epidemiology of type $\mathbf{2}$ diabetes mellitus in pediatric populations. In: Nutrition and Health: Management of Pediatric Obesity and Diabetes, Edited by: Ferry Jr. RJ. New York, Springer 2011, 251-264. | Article

3. Morrison J A, Glueck C J, Woo J G and Wang P: Risk factors for cardiovascular disease and type 2 diabetes retained from childhood to adulthood predict adult outcomes: the Princeton LRC Followup Study. Int J Pediatr Endocrinol 2012, 2012:6. | Article | PubMed Abstract | PubMed Full Text

4. Kester LM, Hey $\mathrm{H}$ and Hannon TS: Using hemoglobin A1c for prediabetes and diabetes diagnosis in adolescents: can adult recommendations be upheld for pediatric use? J Adolesc Health 2012, 50: 321-3. | Article | PubMed

5. Greig F, Hyman S, Wallach E, Hildebrandt T and Rapaport R: Which obese youth are increased risk for type 2 diabetes? Latent class analysis and comparison with diabetic youth. Pediatr Diabetes 2012, 13: 181-8. | Article | PubMed

6. Wood JR, Kaufman and FR: Childhood diabetes In: Atlas of Diabetes, eth ed. Edited by Skyler, JS. New York, Springer 2012, 115-148.

7. HEALTHY Study Group, Kaufman FR, Hirst K, Linder B, Baranowski T: Risk factors for type $\mathbf{2}$ diabetes in a sixth- grade multiracial cohort: the HEALTHY study. DiabetesCare 2009, 32: 953-5. | Article | PubMed Abstract | PubMed Full Text

8. Gupta N, Goel K, Shah P and Misra A: Childhood obesity in developing countries: epidemiology, determinants, and prevention. Endocr Rev. 2012, 33: 48-70. | Article | PubMed

9. The Mayo Clinic: Type 2 diabetes. Retrieved on August 28, 2012 from -2-diabetes/ds00585. | Article

10. Wilmot E G, Davies M J, Yates T, Benhalima K, Lawrence I G and Khunti K: Type 2 diabetes in younger adults: the emerging UK epidemic. Postgrad Med J 2010, 86:711-8. | Article |PubMed

11. D'Adamo E and Caprio S: Type 2 diabetes in youth: epidemiology and pathophysiology. Diabetes Care 2011, 34 Suppl 2: S161-5. | Article I PubMed

12. Choo K E, Lau K B, Davis W A, Chew P H, Jenkins A J and Davis T $M$ : Cardiovascular risk factors in pre-pubertal Malays: effects of diabetic parentage. Diabetes Res Clin Pract 2007, 76:119-25. | Article I PubMed

13. Wei J N, Li H Y, Wang Y C, Chuang L M, Lin M S, Lin C H and Sung F C: Detailed family history of diabetes identified children at risk of type 2 diabetes: a population-based case-control study. Pediatr Diabetes 2010, 11:258-64. | Article | PubMed

14. Awa W L, Fach E, Krakow D, Welp R, Kunder J, Voll A, Zeyfang A, Wagner C, Schutt M, Boehm B, de Souza M and Holl R W: Type 2 diabetes from pediatric to geriatric age: analysis of gender and obesity among 120,183 patients from the German/Austrian DPV database. Eur J Endocrinol 2012, 167:245-54. | Article | PubMed

15. Oh YJ, Nam HK, Rhie YJ, Park SH and Lee KH: Low Serum Adiponectin levels in Korean children with a family history of type 2 diabetes mellitus. Horm. Res. Paediatr. 2012, 77: 382-387. | Article | PubMed

16. Morgan AR: Determining genetic risk factors for pediatric type 2 diabetes. Curr Diab Rep. 2012, 12: 88-92. | Article | PubMed

17. Amed S, Hamilton J K, Sellers E A, Panagiotopoulos C, Hadjiyannakis S, Shah B R, Booth G L, Laubscher T A, Dannenbaum D and Dean H: Differing clinical features in Aboriginal vs. non-Aboriginal children presenting with type 2 diabetes. Pediatr Diabetes 2012, 13:470-5. I Article | PubMed

18. Liu L L, Lawrence J M, Davis C, Liese A D, Pettitt D J, Pihoker C, Dabelea D, Hamman R, Waitzfelder B and Kahn H S: Prevalence of overweight and obesity in youth with diabetes in USA: the SEARCH for Diabetes in Youth study. Pediatr Diabetes 2010, 11:4-11. | Article PubMed

19. Urakami T, Suzuki J, Yoshida A, Saito H and Wada M: Prevalence of components of the metabolic syndrome in schoolchildren with newly diagnosed type 2 diabetes mellitus. Pediatr Diabetes 2009, 10: 508-12. | Article | PubMed

20. Urakami T, Habu M, Kuwabara R, Komiya K, Nagano N, Suzuki J and Mugishima $\mathrm{H}$ : Insulin resistance at diagnosis in Japanese children with type 2 diabetes mellitus. Pediatr Int 2012, 54:516-9. | Article |
PubMed

21. Rosenbloom AL, Silverstein JH, Amemiya $S$, Zeitler $P$ and Klingensmith GJ: Type 2 diabetes in children and adolescents. Pediatr Diabetes 2009, 10 Suppl 12: 17-32. | Article | PubMed

22. Widen E, Silventoinen K, Sovio U, Ripatti S, Cousminer D L, Hartikainen A L, Laitinen J, Pouta A, Kaprio J, Jarvelin M R, Peltonen $L$ and Palotie A: Pubertal timing and growth influences cardiometabolic risk factors in adult males and females. Diabetes Care 2012, 35:850-6. | Article | PubMed

23. Chen L, Zhang C, Yeung E, Ye A, Mumford S L, Wactawski-Wende J and Schisterman E F: Age at menarche and metabolic markers for type 2 diabetes in premenopausal women: the BioCycle Study. J Clin Endocrinol Metab 2011, 96:E1007-12. | Article | PubMed Abstract | PubMed Full Text

24. Levitt Katz LE, Magge S N, Hernandez M L, Murphy K M, McKnight H M and Lipman T: Glycemic control in youth with type 2 diabetes declines as early as two years after diagnosis. J Pediatr 2011, 158:106-11. | Article | PubMed

25. Zeitler P: Considerations regarding the diagnosis and treatment of childhood type 2 diabetes. Postgrad Med. 2010, 122: 89-97. | Article PubMed

26. Wong K, Potter A, Mulvaney S, Russell W E, Schlundt D G and Rothman R L: Pediatric endocrinologists' management of children with type 2 diabetes. Diabetes Care 2010, 33:512-4. | Article | PubMed Abstract | PubMed Full Text

27. Badaru A and Pihoker C: Type 2 diabetes in childhood: clinical characteristics and role of $\beta$-cell autoimmunity. Curr Diab Rep. 2012, 12: 75-81. | Article | PubMed

28. Caprio S: Development of Type 2 Diabetes Mellitus in the Obese Adolescent: A Growing challenge. Endocr Pract. 2012, 18: 791-5. | Article I PubMed

29. Jefferies C, Carter P, Reed P W, Cutfield W, Mouat F, Hofman P L and Gunn A J: The incidence, clinical features, and treatment of type 2 diabetes in children \&lt; $15 \mathrm{yr}$ in a population-based cohort from Auckland, New Zealand, 1995-2007. Pediatr Diabetes 2012, 13:294300. | Article | PubMed

30. Shaibi GQ, Michaliszyn SB, Fritschi C, Quinn L and Faulkner MS: Type 2 diabetes in youth: a phenotype of poor cardiorespiratory fitness and low physical activity. Int J Pediatr Obes. 2009, 4: 332-7. | Article | PubMed Abstract | PubMed Full Text

31. Perez-Mendez O, Torres-Tamayo M, Posadas-Romero C, Vidaure Garces V, Carreon-Torres E, Mendoza-Perez E, Medina Urrutia A, Huesca-Gomez C, Zamora-Gonzalez J and Aguilar-Herrera B: Abnormal HDL subclasses distribution in overweight children with insulin resistance or type $\mathbf{2}$ diabetes mellitus. Clin Chim Acta 2007, 376:17-22. | Article | PubMed

32. Mizokami-Stout K, Cree-Green M and Nadeau KJ: Insulin resistance in type 2 diabetic youth. Curr Opin Endocrinol Diabetes Obes. 2012, 19: 255-62. | Article | PubMed

33. Vaidyanathan J, Choe $S$ and Sahajwalla CG: Type 2 diabetes in pediatrics and adults: thoughts from a clinical pharmacology perspective. J Pharm Sci. 2012, 101: 1659-71. | Article | PubMed

34. Stringer DM, Sellers EA, Burr LL and Taylor CG: Altered plasma adipokines and markers of oxidative stress suggest increased risk of cardiovascular disease in First Nation youth with obesity or type 2 diabetes mellitus. Pediatr Diabetes 2009, 10: 269-77. | Article | PubMed

35. Urbina EM, Kimball TR, McCoy CE, Khoury PR, Daniels SR and Dolan LM: Youth with obesity and obesity-related type 2 diabetes mellitus demonstrate abnormalities in carotid structure and function. Circulation 2009, 119: 2913-9. | Article | PubMed Abstract | PubMed Full Text

36. Naylor L H, Green D J, Jones T W, Kalic R J, Suriano K L, Shah M, Hopkins $N$ and Davis $E$ A: Endothelial function and carotid intimamedial thickness in adolescents with type 2 diabetes mellitus. $J$ Pediatr 2011, 159:971-4. | Article | PubMed

37. Cerutti F, Rabbia F, Rabbone I, Bobbio A, Ignaccolo M G, Greco G, Bertello M C, Mulatero P, Veglio F and Pacini G: Impairment of cardiovascular autonomic pattern in obese adolescents with Type 2 diabetes mellitus. J Endocrinol Invest 2010, 33:539-43. | Article | PubMed

38. Kotb NA, Gaber R, Salama M, Nagy HM and Elhendy A: Clinical and 
biochemical predictors of increased carotid intima-media thickness in overweight and obese adolescents with type $\mathbf{2}$ diabetes. Diab Vasc Dis Res. 2012, 9: 35-41. | Article | PubMed

39. Shah AS, Dolan LM, Gao Z, Kimball TR and Urbina EM: Racial differences in arterial stiffness among adolescents and young adults with type 2 diabetes. Pediatr Diabetes 2012, 13: 170-5. | Article | PubMed

40. Urbina EM, Gao Z, Khoury PR, Martin LJ and Dolan LM: Insulin resistance and arterial stiffness in healthy adolescents and young adults. Diabetologia 2012, 55: 625-31. | Article | PubMed

41. Amutha A, Datta M, Unnikrishnan R, Anjana RM and Mohan V: Clinical profile and complications of childhood- and adolescentonset type 2 diabetes seen at a diabetes center in south India. Diabetes Technol Ther. 2012; 14; 497-504. | Article | PubMed

42. El Asrar MA, Adly AA, El Hadidy ES and Abdelwahab MA: D-dimer levels in type 1 and type 2 diabetic children and adolescents; Relation to microvascular complications and dyslipidemia "own data and review". Pediatr Endocrinol Rev.; 2012, 9: 657-68. | PubMed

43. Bronson-Castain K W, Bearse M A, Jr., Neuville J, Jonasdottir S, King-Hooper B, Barez S, Schneck M E and Adams A J: Early neural and vascular changes in the adolescent type 1 and type 2 diabetic retina. Retina 2012, 32:92-102. | Article | PubMed

44. Sultan MB, Starita $C$ and Huang K: Epidemiology, risk factors and management of paediatric diabetic retinopathy. Br J Ophthalmol 2012, 96: 312-7. | Article | PubMed

45. Bruehl H, Sweat V, Tirsi A, Shah B and Convit A: Obese Adolescents with Type 2 Diabetes Mellitus Have Hippocampal and Frontal Lobe Volume Reductions. Neurosci Med. 2011, 2: 34-42. | Article | PubMed Abstract | PubMed Full Text

46. Newfield RS, Dewan AK and Jain S: Dyslipidemia in children with type 2 diabetes vs. obesity. Pediatr Diabetes 2008, 9: 115-21. | Article | PubMed

47. Halfon N, Verhoef PA and Kuo AA: Childhood antecedents to adult cardiovascular disease. Pediatr Rev. 2012, 33: 51-60. | Article | PubMed

48. Dean $\mathrm{HJ}$ and Sellers EA: Comorbidities and microvascular complications of type $\mathbf{2}$ diabetes in children and adolescents. Pediatr Diabetes 2007, 8 Suppl 9: 35-41. | Article | PubMed

49. Eppens M C, Craig M E, Cusumano J, Hing S, Chan A K, Howard N J, Silink $M$ and Donaghue K C: Prevalence of diabetes complications in adolescents with type $\mathbf{2}$ compared with type 1 diabetes. Diabetes Care 2006, 29:1300-6. | Article | PubMed

50. Zeitler P: Approach to the obese adolescent with new-onset diabetes. J Clin Endocrinol Metab. 2010, 92: 5163-70. | Article | PubMed Abstract | PubMed Full Text

51. Eppens M C, Craig M E, Jones T W, Silink M, Ong S and Ping Y J: Type 2 diabetes in youth from the Western Pacific region: glycaemic control, diabetes care and complications. Curr Med Res Opin 2006, 22:1013-20. | Article | PubMed

52. Pan C Y, So W Y, Khalid B A, Mohan V, Thai A C, Zimmet P, Cockram C $S$, Jorgensen $L N$ and Yeo J P: Metabolic, immunological and clinical characteristics in newly diagnosed Asian diabetes patients aged 1240 years. Diabet Med 2004, 21:1007-13. | Article | PubMed

53. Lim T O, Ding L M, Goh B L, Zaki M, Suleiman A B, Maimunah A H, Rozita $\mathrm{H}$ and Rashid $\mathrm{A}$ : Distribution of blood pressure in a national sample of Malaysian adults. Med J Malaysia 2000, 55:90-107. | PubMed

54. Schwimmer JB, Pardee PE, Lavine JE, Blumkin AK and Cook S: Cardiovascular risk factors and the metabolic syndrome in pediatric nonalcoholic fatty liver disease. Circulation 2008, 118: 277-83. | Article | PubMed Abstract | PubMed Full Text

55. Wittmeier K D, Wicklow B A, Maclntosh A C, Sellers E A, Ryner L N, Serrai H, Gardiner P F, Dean H J and McGavock J M: Hepatic steatosis and low cardiorespiratory fitness in youth with type 2 diabetes. Obesity (Silver Spring) 2012, 20:1034-40. | Article | PubMed

56. Nwosu BU, Stavre ZG, Maranda L, Cullen K and Lee MM: Hepatic dysfunction is associated with vitamin $D$ deficiency and poor glycemic control in diabetes mellitus. J Pediatr Endocrinol Metab. 2012, 25: 181-6. | Article | PubMed

57. Kim JS, Lê KA, Mahurkar S, Davis JN and Goran MI: Influence of elevated liver fat on circulating adipocytokines and insulin resistance in obese Hispanic adolescents. Pediatr Obes. 2012, 7:
158-64. | Article | PubMed

58. Nadeau KJ, Klingensmith $\mathrm{G}$ and Zeitler P: Type 2 diabetes in children is frequently associated with elevated alanine aminotransferase. $J$ Pediatr Gastroenterol Nutr. 2005, 41: 94-8. | Article | PubMed

59. Pacifico L, Nobili V, Anania C, Verdecchia P and Chiesa C: Pediatric nonalcoholic fatty liver disease, metabolic syndrome and cardiovascular risk. World I Gastroenterol. 2011, 17: 3082-91. | Article | PubMed Abstract | PubMed Full Text

60. Bellentani S, Scaglioni F, Marino M and Bedogni G: Epidemiology of non-alcoholic fatty liver disease. Dig Dis. 2010, 28: 155-61. | Article I PubMed

61. Widhalm $K$ and Ghods E: Nonalcoholic fatty liver disease: a challenge for pediatricians. Int J Obes (Lond). 2010, 34: 1451-67. | Article | PubMed

62. Gronbaek H, Lange A, Birkebaek N H, Holland-Fischer P, Solvig J, Horlyck A, Kristensen K, Rittig $S$ and Vilstrup H: Effect of a 10-week weight loss camp on fatty liver disease and insulin sensitivity in obese Danish children. J Pediatr Gastroenterol Nutr 2012, 54:223-8. | Article | PubMed

63. Alisi A, Locatelli $M$ and Nobili V: Nonalcoholic fatty liver disease in children. Curr Opin Clin Nutr Metab Care 2010, 13: 397-402. I Article PubMed

64. Rashid $\mathrm{M}$ and Roberts EA: Nonalcoholic steatohepatitis in children. J Pediatr Gastroenterol Nutr. 2000, 30: 48-53 | Article | PubMed

65. Poggiogalle E, Olivero G, Anania C, Ferraro F and Pacifico L: Pediatric non-alcoholic fatty liver disease: recent advances and challenges. Minerva Pediatr. 2010, 62: 569-84. | Article | PubMed

66. Sjaarda L A, Michaliszyn S F, Lee S, Tfayli H, Bacha F, Farchoukh L and Arslanian S A: HbA1c Diagnostic Categories and $\beta$-Cell Function Relative to Insulin Sensitivity in Overweight/Obese Adolescents. Diabetes Care 2012, 35:2559-63. | Article | PubMed

67. Bacha, F, Gungor N, Lee S and Arslanian SA: Progressive deterioration of $\beta$-cell function in obese youth with type 2 diabetes. Pediatr. Diabetes 2012; [Epub ahead of print]. | Article | PubMed

68. Elder D A, Herbers P M, Weis T, Standiford D, Woo J G and D'Alessio $D A: \beta$-cell dysfunction in adolescents and adults with newly diagnosed type 2 diabetes mellitus. J Pediatr 2012, 160:904-10. | Article | PubMed

69. Lesser D J, Bhatia R, Tran W H, Oliveira F, Ortega R, Keens T G, Mittelman S D, Khoo M C and Davidson Ward S L: Sleep fragmentation and intermittent hypoxemia are associated with decreased insulin sensitivity in obese adolescent Latino males. Pediatr Res 2012, 72:293-8. | Article | PubMed Abstract | PubMed Full Text

70. Bogdanović $\mathrm{R}$ : Diabetic nephropathy in children and adolescents. Pediatr Nephrol. 2008, 23: 507-25. | Article | PubMed

71. Bulloch B, Postl BD and Ogborn MR: Excess prevalence of non diabetic renal disease in native American children in Manitoba. Pediatr Nephrol. 1996, 10: 702-4. | Article | PubMed

72. Dart A B, Sellers E A, Martens P J and Rigatto C, Brownell M D and Dean $\mathrm{H}$ J: High burden of kidney disease in youth-onset type 2 diabetes. Diabetes Care 2012, 35:1265-71. | Article | PubMed

73. Dart AB, Sellers EA and Dean HJ: Kidney disease and youth onset type 2 diabetes: considerations for the general practitioner. Int $J$ Pediatr. 2012, 237360. | Article | PubMed Abstract | PubMed Full Text

74. Savino A, Pelliccia P, Chiarelli F and Mohn A: Obesity-related renal injury in childhood. Horm Res Paediatr. 2010, 73: 303-11. | Article | PubMed

75. Mueller PW and Caudill SP: Urinary albumin excretion in children: factors related to elevated excretion in the United States population. Ren Fail. 1999, 21: 293-302. | Article | PubMed

76. Faulkner MS, Quinn L and Fritschi C: Microalbuminuria and heart rate variability in adolescents with diabetes. $J$ Pediatr Health Care 2010, 24: 34-41. | Article | PubMed Abstract | PubMed Full Text

77. Sellers E A, Blydt-Hansen T D, Dean H J, Gibson I W, Birk P E and Ogborn M: Macroalbuminuria and renal pathology in First Nation youth with type 2 diabetes. Diabetes Care 2009, 32:786-90. | Article | PubMed Abstract | PubMed Full Text 